\title{
KELETI VALLÁSI MOTÍVUMOK A KORAI MAGYARSÁGGAL KAPCSOLATBA HOZHATÓ RÉGÉSZETI KULTÚRÁKBAN
}

\author{
KLIMA LÁSZLÓ*
}

\begin{abstract}
A tanulmány a Szubotci-horizonthoz tartozó szubotci, katyerinovkai és novonyikolajevkai veretek, valamint a dél-uráli isimbaji, a felső-kámai redikori lelőhelyről származó veretek és a Verhnyij Szaltov, Bolsije Tyigani temetőiből ismert párhuzamaik képi motívumainak eredetét kutatja történeti forrásokra, folklorisztikai és vallástörténeti adatokra támaszkodva.
\end{abstract}

Kulcsszavak: Szubotci-horizont, Dél-Urál, Felsô-Káma, övveretek, buddhista/manicheista hatás

The study explores the sources of images on belt mounts from the Subotsi Horizon (Subotsi, Katerinovka, Novonikolaevka), Ishimbay (Southern Urals) and Redikor (Upper Kama) and their parallels from the Bolshie Tigani cemetery and Verkhniy Saltov based on historical sources, and date from the folklore and religious history.

Keywords: Subotsi Horizon, Southern Urals, Upper Kama, belt mounts, Buddhist/Manichaeist influence

Jelen írásomban egyes régészeti leletek - emberalakos ábrázolások - képi motívumainak eredetét próbálom megvilágítani - történeti forrásokra, folklorisztikai és vallástörténeti adatokra hivatkozva. Az itt tárgyalt övveretek a korai magyarsággal kapcsolatba hozható Szubotcihorizont, a dél-uráli karajakupovói/kusnarenkovói kultúra és a Felső-Káma-vidéki lomovatovói kultúra köréből származnak.

\section{A korai magyar régészeti leletek ember- és állatalakos motívumainak kutatási lehetóségeiról és irányairól}

Honfoglalás kori régészeti leleteink körében az általánosan jellemző növényi ornamentika mellett elenyésző kisebbséget képviselnek az állatés emberalakos ábrázolások. A korongokon, tarsolylemezeken, övvereteken és egyéb ruhadíszeken ragadozó madarak, négylábúak (szarvas, róka), lovak lovassal és képzelt lények (szenmurv, griff, egyszarvú) a jellemző ábrázolások. ${ }^{1}$ Időben

\footnotetext{
Kézirat beérkezett: 2019. április 10 .

* Klima László: ELTE BTK Finnugor Tanszék 1088 Budapest Múzeum krt. 4.; e-mail: klima.laszlo@btk.elte.hu

1 Felsorolásuk: BOLLÓK 2015, 5-6.
}

visszafelé lépve, az avar kori leleteken több állatábrázolást találunk: legtöbbször griffeket, illetve a nagyszijjvégeken három állat küzdelmét. ${ }^{2} \mathrm{Az}$ állat- és emberábrázolásokat tekintve az avar korban külön kategóriát képvisel a nagyszentmiklósi kincs. ${ }^{3}$

A magyar régészetben vannak hagyományai a leletek múvészettörténeti és folklorisztikai megközelítésének. Bálint Csanád a honfoglalás kori áttört, illetve lemezes korongok lóábrázolásait elemezve azt a véleményt fogalmazta meg, hogy a ló hátából kisarjadó növényi ornamentika esetleg egy mitikus lovas szimbólumaként értelmezhető. ${ }^{4}$ A 10-12. századi temetőkből ismert, olykor félbevágott kutyamaradványok alapján pedig a kutyaesküre vonatkozó történeti forrásokat és a kutyákhoz kapcsolódó hiedelmeket, totemisztikus képzeteket tárgyalta. ${ }^{5}$ Fodor István a karosi veretek, a rakamazi és zempléni hajfonatkorongok ragadozómadár-ábrázolásaiból kiindulva a sas szerepét elemezte a honfoglaló magyarság körében, eurázsiai párhuzamokra hivatkozva. $^{6}$

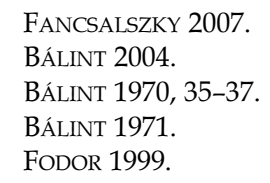


A múvészettörténeti és folklorisztikai elemzés azonban fokozatosan háttérbe szorult. Marosi Ernő 1996-os tanulmánya zárófejezetében megállapította, hogy a Nemzeti Múzeum honfoglalás kori kiállítása nem fordít figyelmet a bemutatott régészeti emlékanyag múvészettörténeti értelmezésére. Ugyanott Alois Riegl 1893-as Stilfragen címú múvére hivatkozva elutasította a honfoglaláskor kutatói körében népszerú állítást, hogy a palmettaornamentika a sámánhit világfa-elképzeléséból vezethető le, és a honfoglalók fémmúvességében az iráni-szogd kultúrkörből ered. ${ }^{7}$

A régészetnek a múvészettörténeti elemzéstől és a folklorisztikai párhuzamoktól való eltávolodását láthatjuk Bálint Csanádnak a nagyszentmiklósi kincsről írt monográfiájában is: a szerző idézi ugyan a szakirodalomból ismert véleményeket a kincs egyes edényein látható ember- és állatábrázolásokról, de azok értelmezését nem látja lehetségesnek, ezért nem vállalkozik az ábrázolások ikonográfiai és ikonológiai elemzésére. ${ }^{8}$ A honfoglalás kori leletek múvészettörténeti elemzése Bollók Ádám munkássága nyomán magasabb szintre emelkedett. A 10. századi Kárpátmedencei ornamentikáról írt monográfiájában az állatábrázolásos tiszabezdédi tarsolylemez és rakamazi hajfonatkorongpár múvészettörténeti elemzését is olvashatjuk. ${ }^{9}$ A szerző ezzel ajtót nyitott a régészet és a múvészettörténet közé az elmúlt évtizedekben emelt falon.

A 20. század közepétől a régészet és a tárgyi néprajz is eltávolodott egymástól. A néprajz már nem őstörténeti tudományként definiálja önmagát. Kósa László véleménye szerint a hagyományos magyar paraszti és kisipari múveltség újkori hagyományokhoz kötődik, nem kapcsolódik a honfoglalás körüli idők kultúrájához. ${ }^{10}$ Voigt Vilmos már az 1970-es években felhívta a figyelmet a folklorisztikának a honfoglalók kultúrájának, ősköltészetének kutatása terén elkövetett "tévelygéseire". ${ }^{11}$ A régészet és a múvészettörténet, a régészet és a néprajz kapcsolattörténetét a honfoglaláskor kutatásában részletesen tárgyalta Langó Péter, közben többször hangsúlyozva, hogy az őstörténeti társtudományokat együtt kezeló kutatók a múltban folyamatosan alkalmazták a kevert érvelés hibás módszerét. ${ }^{12}$ Úgy tűnik, hogy a különböző őstörténeti tudományok múvelői az utóbbi negyedszázadban azért zár-

\footnotetext{
7 Marosi 1996, 1032.

8 BÁLINT 2004, 86., 400: „,egy tudományosan kifogástalan összehasonlítás végigvitele [...] elsősorban a szellemi kultúra megnyilvánulásaival kapcsolatban szinte lehetetlen".

9 BOLLÓK 2015, 429-530.

10 Kósa 1996, 978.

11 VoIGT 1974, 604; 1977, 318.

12 LANGÓ 2007, 193-209.
}

kóztak be a saját tudományuk múvelésébe, mert attól félnek, hogy a szakmai közvélemény a kevert érvelés alkalmazóiként bélyegzi meg őket.

A fent említett és hivatkozott példák az őstörténeti társtudományok együttmúködésének problémájára hívják fel a figyelmet. 2014-ben a Magyar őstörténet - tudomány és hagyományörzés címú konferencián az egyes őstörténeti tudományok bezárkózási törekvéseivel szemben Hoppál Mihály ismét az interdiszciplináris együttmúködés mellett érvelt: „a bölcsészettudományok mindegyikének volt, vagy van mondanivalója az őstörténet-kutatás számára. [...] ezeknek a kutatásterületeknek az eredményeit együtt kellene látni!"13

A magyar ősvalláskutatás (új) útjairól szólván Hoppál Mihály az elmúlt negyedszázad eredményeire hivatkozva megállapította, hogy a „folklór, a szájhagyomány meglepóen állandó motívumokkal, térben és időben ugyan távol, de hasonló elemekkel dolgozik". ${ }^{14} \mathrm{Az}$ általa hivatkozott kutatók közül Jurij Berjozkin a szibériai és amerikai őslakos mitológiákat a motívumok alapján hasonlítja össze. A szerző motívumként értékeli azokat az epizódokat vagy múvészi eszközöket (metaforákat, hasonlatokat stb.), amelyek egynél több szövegben fordulnak elő. ${ }^{15}$ A mitológiai motívumokhoz hasonlóan a világvallások szöveges és képi motívumai is nagy területeket és korszakokat fognak át. Ehhez a felismeréshez a múvészettörténet már korábban eljutott. A motívumok vizsgálatával nem eseménytörténeti következtetésekhez jutunk, hanem a szövegeket ránk hagyó emberi közösségek gondolatvilágába pillanthatunk be. Ha egy adott korszakból nem állnak rendelkezésünkre szövegek, csak tárgyi emlékek, azok motívumainak elemzésével is közelebb juthatunk az egykor élt emberekhez, hozzávetőleges képet kaphatunk a világszemléletüket meghatározó mitológiai és vallási sémákról.

\section{Emberalakos csat a szubotci 2. sírból}

A Szovjetszkaja Arheologija címú folyóiratban 1988-ban jelent meg Ninyel Bokij és Szvetlana Pletnyova közös cikke a Szubotciban feltárt sírokról. Egy évvel később a közlemény megjelent

13 Hoppál 2014, 231.

14 Hoppál 2014, 233, a hivatkozott múvek: DEMÉNY 2002, BERJOZKIN 2007, NAPOLSKIKH 1989.

15 BERJOZKIN 2007, 166: „motívum lehet bármilyen epizód vagy kép, illetve epizódok és képek kombinációja, amennyiben több szövegben fordulnak elö". 


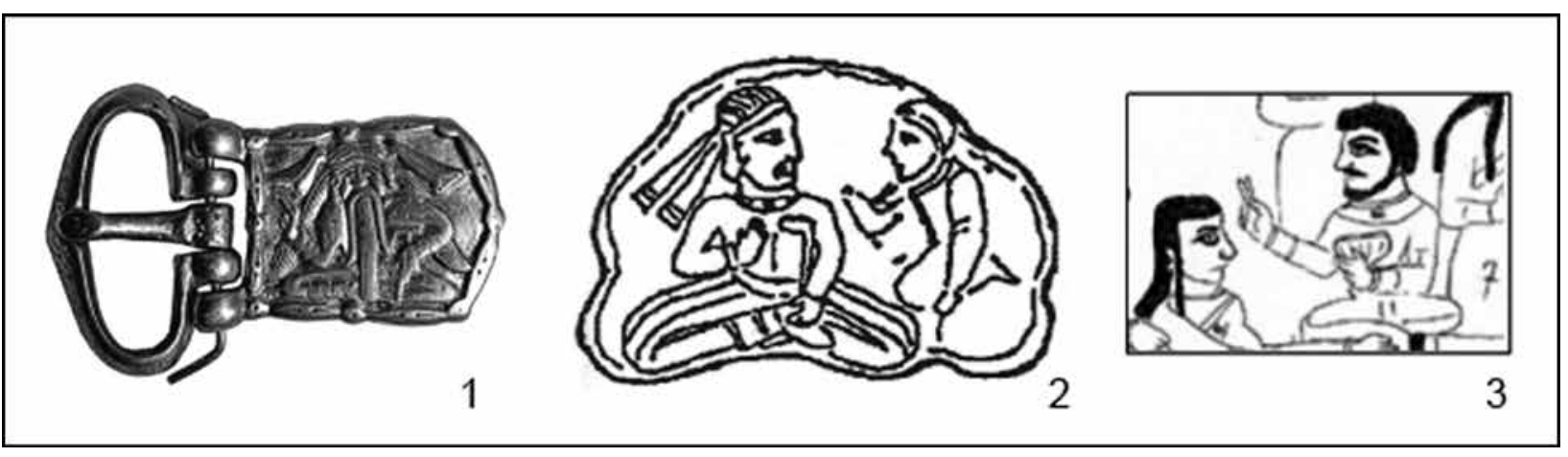

1. kép. Emberábrázolások. 1: Csat. Szubotci. (KOMAR 2018, 327. 12. kép/4.); 2: Veret. Verhnyij Szaltov. (AKszjONOv 2001, 139.); 3: Váza részlet. Merv. (COMPARETTI 2011, 26.)

Fig 1. Human figures. 1: Buckle plate. Subotsi. (KoMAR 2018, 327. fig. 12/4.); 2: Belt mount. Verkhniy Saltov. (AKSENOV 2001, 139.); 3: Vase, detail. Merv. (COMPARETTI 2011, 26.)

magyarul is az Archaeologiai Értesítóben. ${ }^{16}$ A szerzők a 2. sírban talált tmutarakanyi típusú korsót a 10. század 2. felére keltezték. ${ }^{17}$ Ugyanakkor a leletanyag a honfoglaló magyarok leleteivel mutat kapcsolatot. E két tényezó alapján Bokij és Pletnyova úgy vélték, hogy a háromsíros kis családi temetó a keleten leszakadt és a besenyőkkel együtt élt magyar népesség emléke. ${ }^{18}$ A Szubotciban talált leleteket, valamint az Ukrajna és Moldova területéról származó hasonló jellegú leleteket Olekszij Komar rendszerezte. ${ }^{19}$ Publikációja nyomán a szakirodalom a Szubotci-típusú leletek, illetve a Szubotci-horizont elnevezést használja erre a jól körülhatárolható leletegyüttesre. Felülbírálva Bokij és Pletnyova datálását, Komar a Szubotciból származó sírokat, illetve az egész horizontot a 9. század közepére, második felére datálta. Ezt ${ }^{14} \mathrm{C}$-vizsgálatok is igazolják. ${ }^{20}$

A háromsíros, feltehetőleg családi temetkezés 2. sírjában férfi nyugodott. A veretes övéhez tartozó csat testén lótuszülésben ülő idős férfi alakja figyelhető meg. Hosszú haja, bajusza és szakálla van, ez utóbbi a térdéig ér. Feje mindkét oldalán trapéz alakú forma (különleges hajviselet vagy fátyol?) látható. Gömbcsüngós fülbevalót visel, haját homlokán pánt/diadém fogja össze. Bal kezében T-végú bot látható. Jobb kezével áldást oszt: karját felfelé nyújtja, három ujja be van

16 BoKiJ-Pletnyova 1988, BOKIJ-Pletnyova 1989 (fordította: Erdélyi István).

17 BOKIJ-PletNYYOVA 1989, 95.

18 Bokij-Pletnyova 1989, 97.

19 KOMAR 2011.

20 KOMAR 2011, 68-69; 2018, 148-152. Ez a datálás nem általánosan elfogadott, ugyanakkor a kutatók egyöntetúen a magyarság elődeihez kapcsolják a Szubotci-horizont leleteit. A motívumok kapcsolatrendszerének vizsgálata a datálási problémák ellenére is elvégezhető. hajlítva, mutató- és középső ujja felfelé mutat (1. kép 1).

A szubotci 2. sír csatjának üló alakjához a szaszanida-szogd fémmúvesség köréból idézett párhuzamokat Türk Attilaa ${ }^{21}$ és Olekszij Komar. ${ }^{22}$ $\mathrm{T}(\mathrm{tau})$-alakú bottal ábrázoltak egy öregembert a Szaltovo-majaki kulturális történeti egység területéról, Verhnyij Szaltovból 1985-ben elókerült töredékes vereten (1. kép 2). Ugyanabból a Verhnyij Szaltov-i sírból ismert egy másik veret, szintén lótuszülésben ülő figurával. ${ }^{23}$

\section{A csat emberábrázolásának korábbi értelmezési kísérletei}

Az öv csatjának lemezén lótuszülésben látható idős férfi Mesterházy Károly olvasatában az „Atyaistent" ábrázolja. Párhuzamaként a mervi vázán látható egyik jelenetet említette, amely szerinte zoroasztriánus papot ábrázol (1. kép 3). A temetési szertartást vezetó alak ugyanolyan testtartásban ül, mint a szubotci csat öregembere. ${ }^{24}$ A szubotci öregember/istenség homlokán lévő szalagot a diadém tartozékaként, a kezében lévő botot pedig T-fejú pásztorbotként határozta meg. ${ }^{25}$ Mesterházy Károly nem említi, de az övveret és a váza lótuszülésben üló alakjának jobb kézfeje egyformán a krisztusi áldást osztó pozícióban van. A 9. századi kelet-európai sztyeppén Mesterházy Károly szerint erős vallási keveredés volt jellemző. ${ }^{26}$ A mervi vázával kapcsolatban

21 TÜRK 2011, 265., 266. kép.

22 Komar 2016, 547/рис. 2, 549/рис. 3, 552/рис. 4.

23 AKSZjONOv 2001; lásd még KOMAR 2016, 547; 2018, 341, 26/1., 7. kép.

24 A mervi váza jeleneteinek értelmezéséről, mitológiai hátteréről lásd COMPARETTI 2011.

25 Mesterházy 1994, 198, 200.

26 MESTERHÁZY 1994, 197. 
Bálint Csanád kiemelte, hogy egy buddhista sztúpa közeléből került elő. ${ }^{27}$

Galina Korol 2005-ben publikált tanulmányában a szubotci öv vereteinek motívumait az oszét Nart-eposszal hozta kapcsolatba. ${ }^{28}$ Vlagyimir Petruhin egy feltételezett eurázsiai kozmogonikus mítosszal hozta összefüggésbe a csattesten ábrázolt férfialakot, akit a mítoszban egymással örök küzdelmet vívó férfiak közül a hosszú hajú szereplővel azonosított. ${ }^{29}$ 2016-ban megjelent tanulmányában Olekszij Komar a szakállas öregembert taoista tanítóhoz hasonlította. Véleménye szerint a tárgyat készítő ötvös az emberalak ábrázolásában buddhista vagy taoista ikonográfiai elemeket alkalmazott. ${ }^{30}$ 2018-as összefoglalásában a szubotci övcsat emberalakját az „uralkodó" motívumkör keretében tárgyalta. A jobb kéz tartását keleti módú áldásosztásnak nevezte, és megállapította, hogy amennyiben az ötvös tisztában volt e kéztartás jelentőségével, „,akkor ez az emberalak nem uralkodót, hanem egy idős nemzetségfőt vagy egy bölcset ábrázol" ${ }^{31} \mathrm{Az}$ emberalakos övveretek párhuzamait összegyújtó és csoportokba rendező Olekszij Komar csak két típusnál utal az esetleges mitológiai/vallási háttérre. Ugyanakkor megjegyzi, hogy a veretek készítői nem ismerték az eredeti vallási motívumok jelentését. ${ }^{32}$

\section{A csattesten ábrázolt bölcs öregember - a manicheizmus mint lehetséges kulturális háttér}

A csat leírásakor a férfi ülőpozícióját lótuszülésnek neveztem. Ez már része az általam javasolt értelmezésnek. A sztyeppei nomád kultúrkörben általános pihenőhelyzet a talajon vagy valamilyen puhább tárgyon a test alá húzott lábakkal ülni. Nem véletlen, hogy ezt a testhelyzetet a magyar nyelv "törökülésnek" nevezi. A szakirodalomból ismert tárgyakon szaszanida uralkodókat ábrázoltak a töröküléshez hasonló testtartásban, olykor táncosok, zenészek körében. Az uralkodók fejdíszként szakrális szimbólumokat viselnek, ezek a zoroasztrizmus köréből magyarázhatók.

Fejdíszeik, különleges kéztartásuk és a kezükben ábrázolt tárgyak alapján egyes lótuszülésben ábrázolt személyek azonban nem azonosíthatók szaszanida uralkodókkal. A Szubotciból származó övvereten ábrázolt öregember attribútumai egyrészt keleti vallási, eredendően buddhista,

\footnotetext{
27 BÁLINT 2004, 248.

28 Korol 2005, 157-158, idézi Komar 2016, 548; 2018, 111.

29 Petruhin 2014, 348.

30 KOMAR 2016, 551.

31 KOMAR 2018, 120.

32 KOMAr 2018, 124-126.
}

másrészt keresztény motívumokból vezethetők le. E motívumok jelenléte alapján az ábrázolt személy (istenség, próféta?) ülópozícióját is lótuszülésként kell értelmeznünk.

$\mathrm{Az}$ öregember feje körül látható pillangószárny-, szalag- vagy fátyolszerú jelenségek személyiségének és létezésének különlegességét jelzik. Ezek a taoizmus egyik alapszövegét, a Zhuangzit, és annak 2. fejezetét juttatják eszünkbe. E fejezet egyik története szerint Zhuang Zou álmában pillangóvá változik. Az álom és a pillangóvá válás itt a halál metaforájaként értelmezhetô. ${ }^{33}$

A jobb kéz áldást osztó kéztartása a buddhista ikonográfiában ismeretlen. Ugyanakkor szakrális jellege a keresztény kultúrkörben általános. $\mathrm{Az}$ öregember T-fejú botot tart a bal kezében, esetleg a botot hónaljához támasztja, ez az ábrázolás alapján nem dönthető el egyértelmúen. ${ }^{34}$ Amennyiben a botot $\mathrm{T}(\mathrm{tau})$-pásztorbotként értelmezzük, akkor az is keresztény motívumnak értékelhető. (Mesterházy Károly T-alakú keresztként határozta meg. ${ }^{35}$ )

A lótuszülésben ülő emberalak hosszú bajuszt és szakállt visel. Arcvonásai mellett feltehetóleg ez a motívum is azt a célt szolgálta, hogy idős embernek lássuk az ábrázolni kívánt személyt. Ezt a motívumot egyetlen párhuzamként kínálkozó vereten sem lehet megfigyelni. Mivel az ábrázolás egyéb motívumai miatt bizonyos, hogy vallási/ mitológiai személy látható a vereten, ezért megemlítem, hogy a török és mongol népek mitológiájában is szerepel egy öregember. A mongoloknál fehér öreg a neve, ó a föld és a víz ura, a jókat támogatja, a gonoszokat üldözi. Egy hozzá idézett imádság szerint fehér ruhában jár, haja és bajusza ősz, kezében olyan botot tart, amely sárkányfejben végződik. Buddhával találkozván ígéretet tett neki, hogy ezután is védelmezni fogja az élőlényeket. Egy másik szöveg szerint a fehér öreg újjászületése után buddhaként fog tovább élni. ${ }^{36} \mathrm{Ez}$ a két történet arra mutat rá, hogy a buddhizmus saját terjedése érdekében igyekezett magába olvasztani a helyi mitológiák egyes elemeit. Egy nagy bottal járó, fehér szakállú igazságosztó öregember több török nép, így a baskírok mitológiájában is szerepel. ${ }^{37} \mathrm{~A}$ fenti folklórpárhuzamok alapján az emberalak bal kezében látható bot nem értelmezhetó egyértelmú tau-pásztorbotként, tehát keresztény motívumként.

33 KÓsA 2008.

34 A Verhnyij Szaltovból származó, és párhuzamként kínálkozó ábrázoláson a lótuszülésben ülő ember támaszkodásra használja a botját. AKSZJONOV 2001.

35 MESTERHÁZY 1994, 200.

36 LŐRINCZ 1975, 22-24.

37 ZARIPOV 1987, 47, 501. 
A csaton ábrázolt öregember testtartásából a buddhista ikonográfia hatására gondolhatunk, ezért meg kell vizsgálnunk, hogy ennek a hatásnak megvolt-e a történeti lehetősége. Eurázsia sztyeppei és erdőssztyeppei övezetében a vallási keveredés évszázadokkal a 9. századi Szubotcihorizont előtt kezdődött, és kiterjedt egészen a sztyeppe távol-keleti végéig is. Buddha tanításai már az i. sz. 1. században eljutottak Kínába. Ettől kezdve a sztyeppe övezetét két irányból: keletről, Kína irányából, és délnyugatról, a Kusán Birodalom területéról is érte buddhista hatás. Buddha tanainak terjesztésében Kína mellett a kusánokkal rokon kelet-iráni típusú nyelvet beszélő szogd kereskedők játszották a fószerepet. A szogd kereskedői elit, ahol csak tudott, rátelepedett az őslakos népekre, és jelentős szerepe volt a formálódó sztyeppei birodalmak létrejöttében is. Az Első Türk Kaganátus hivatalos nyelve a szogd volt, a szogd szövegeket szogd írással jegyezték le. A török nyelvek buddhista alapszókincse részben szogd eredetú.

A buddhizmus sztyeppei terjedéséról kínai utazók is beszámoltak. Wu-k'ung buddhista szerzetes Indiába tartva érintette az akkor éppen a türgesek által uralt nyugati türk területeket is: Szemirecsjét, illetve a Csu/Csuj és az Ili folyók vidékét. A türges kagán, Ocïrlïq (699-706) szintén buddhista volt. Feltehetőleg szogd hatásra, mivel pénzeire szogd nyelvú feliratot veretett. A Csu völgyének buddhista emlékeit több mint száz éve kutatják a régészek. Több feltárásból ismertek kisebb-nagyobb buddhista emlékek, sőt épületek is. Az elmúlt évtizedben egy nagyméretú ülő buddha lábai is előkerültek. ${ }^{38} \mathrm{~A}$ buddhizmus sztyeppei jelenlétéről jelentős szakirodalom született az elmúlt évtizedekben. ${ }^{39}$

A Második Türk Kaganátus a kínai ideológiai és politikai terjeszkedés elleni védekezésül megalkotta saját írását, a türk rovásírást, és az ősök hitéhez, vagyis a tengrizmushoz való visszatérést hirdette. Ez együtt járt a buddhizmus visszaszorításával is. Az újonnan létrejövő Ujgur Kaganátus is elfordult a buddhizmustól, és a manicheizmust támogatta. A szogd származású kereskedő elit szerepet játszott az ujgur állam megalakulásában és a szogd írásból származó ujgur írás létrejöttében is.

A buddhista és keresztény vallási motívumok (lótuszülés, áldást osztó jobb kéz, esetleg a pásztorbot), valamint a török/mongol mitológiából származtatható motívum (nagy szakállú, nagy bajuszú öregember bottal) együttes jelenléte csak

38 TORGOJEV 2012.

39 Például LitvinSKy 1968, Puri 1987, Foltz 1999, ElversKog 2010 (további irodalommal). egy szinkretikus vallás körében képzelhető el. Ez a manicheizmus. Máni, a vallásalapító elismerte a zoroasztrizmus, a buddhizmus és a kereszténység ideiglenes érvényességét. Ötvözte ezen vallások tanításait, hogy megalkossa az új, tökéletes és univerzális vallást. Máni azt hirdette, hogy az ő eljöveteléig három próféta járt e világban: Sákjamuni, vagyis a történelmi buddha, Zoroaszter és Jézus. Máni pedig a negyedik próféta a Földön. A manicheizmus nagyon sok elemet vett át a buddhizmusból, ugyanakkor dualisztikus világképe összeegyeztethető volt a természet erőitól félő, a jó és a rossz szellemekben hívő, sámánokat tisztelő népek hitével is.

A manicheizmus keleti terjeszkedése a 7 . század végén kezdődött. 694-ben egy manicheus püspök látogatott Kínába. Máni és tanítványai elóször az uralkodókat próbálták megtéríteni, majd pedig az előkelőket, különös tekintettel az előkelő származású és vagyonos nőkre. Figyelmet fordítottak a fiatalok megtérítésére is. Máni és követói támogatták a kereskedelmet és a vele összefüggő pénzügyi tevékenységet. A manicheus miszsziós tevékenységet a kereskedelmi utazók végezték, közülük is leginkább a szogd kereskedők. A szogd kereskedelem és a manicheista hittérítés összefonódásáról több szerző is írt. ${ }^{40} \mathrm{~A}$ szogd kultúrába beépült különböző eredetú mítoszok, szimbólumok, a szogd vallási szinkretizmus a pendzsikenti falfreskókon is megfigyelhető. ${ }^{41}$

A szinkretizmus a manicheista múvészet kelet-ázsiai változatában is tükröződik. A Kr. u. 8. század közepétől a 11. század elejéig az Ujgur Birodalom területén keveredtek a buddhista és manicheista motívumok. A prófétákat lótuszülésben ábrázolták, hosszú ruhában, glóriával a fejük fölött. ${ }^{42}$ Jézust is ily módon ábrázolták, kezében kereszttel. ${ }^{43}$ Ismert olyan dombormú is, amelyen egy lótuszülésben ülő angyal keresztet tart a kezében.4

A vallási szinkretizmusra utaló motívumok alapján a szubotci 2. sír övcsatján látható emberalak egy tanító, igazságosztó bölcset ábrázol. Feltehetőleg Mánit, a vallásalapítót, akit a múvész felruházott a török/mongol mitológia fehér öregének attribútumaival is. ${ }^{45}$

40 Pl. Maenchen-Helfen 1951, Foltz 1999, mindkettőt idézi SIMON 2011, 411-413. A buddhizmus és a manicheizmus terjedését, a szogdok ebben játszott szerepét röviden összefoglalja Róna-Tas András kézikönyve: RóNA-TAs 1991, 47-50.

41 BELENYICKIJ-MARSAK 1976.

42 GULÁCSI 2009, 128-129.

43 GULÁCSI 2009, Fig. 1a, 1c; GULÁCSI 2015

44 GULÁCSI 2009: Fig. 4f, PARRY 2005 nyomán.

45 A folklórpárhuzamok megismerése után továbbgondoltam véleményemet. Első értelmezési kísérletemet lásd itt: KLIMA 2018, 140 . 
A novonyikolajevkai szíjvég és dél-uráli, Káma-vidéki párhuzamai

A novonyikolajevkai ${ }^{46}$ kurgánleletek 1902-ben kerültek a Hanenko-gyújteménybe. A leletegyüttes egyértelmúen a Szubotci-horizontba sorolható. A szíjvég ${ }^{47}$ nagyon kopott. Az emberalak elnagyolt kidolgozású. Nadrágot és talán hosszú köpenyt hord, lábfejei egy irányba állnak, két karját behajlítva maga előtt tartja, másik két karját pedig felemeli. Dereka körül talán fátyol vagy kendő látható (2. kép 3). A novonyikolajevkai szíjvég önmagában nem értelmezhető, az ábrázolt alak viselete nem írható le egyértelmúen. A felsorolt jellegzetességek az isimbaji és a redikori veretekkel való összehasonlítás révén állapíthatók meg. Az emberalakos szíjvégről készült fotó alapján nyilvánvaló, hogy ezen a tárgyon ugyanazt a személyt kívánták ábrázolni, mint az isimbaji és redikori szíjvégen.

\section{Az isimbaji szijvég}

A 19. század vége óta kutatott isimbaji lelőhelyen N. A. Mazsitov az 1960-as években további három kurgánt tárt föl. A 3. kurgán 3. sírja feltehetóleg jelképes temetkezés volt, emberi csont- maradványokat nem tartalmazott. Az eléggé elnagyolt kidolgozású övveretről közölt kép alapján a veret egy férfit ábrázol. Erre arcvonásaiból és bajuszából következtethetünk. Ruházata feltehetőleg hosszú köpeny, amelyet derekán öv fog össze. ${ }^{48}$ Véleményem szerint a múvész az övvereten többkarú emberalakot kívánt ábrázolni. A két vállból fölfelé az istenség további két karja ágazik ki, a többkarú istenségek ábrázolásához hasonlóan, könyökben meghajlítva (2. kép 1).

\section{A redikori szijuég és csat}

Redikor a Felső-Káma vidékén a Visera folyó mellékén található. A komi-permjákok ősi földje különösen gazdag a 9-10. századi kereskedelmi kapcsolatok emlékeiben. A Káma, a Visera és a Kolva folyók által határolt területet „ezüst háromszögnek" is nevezik. Redikorból számos szórványlelet és temetkezés ismert, a redikori gorogyiscse (földvár) területén is folytak régészeti feltárások. A lomovatovói kultúrához tartozó, az isimbaji szíjvéggel párhuzamba állítható redikori leletek 1909-ben kerültek elö. ${ }^{49} \mathrm{Az}$ aranyozott ezüstból készült tárgyakon a fej ábrázolása groteszkre sikerült. A csattesten kevésbé, azonban a szíjvégen jobban kivehető, hogy a fej

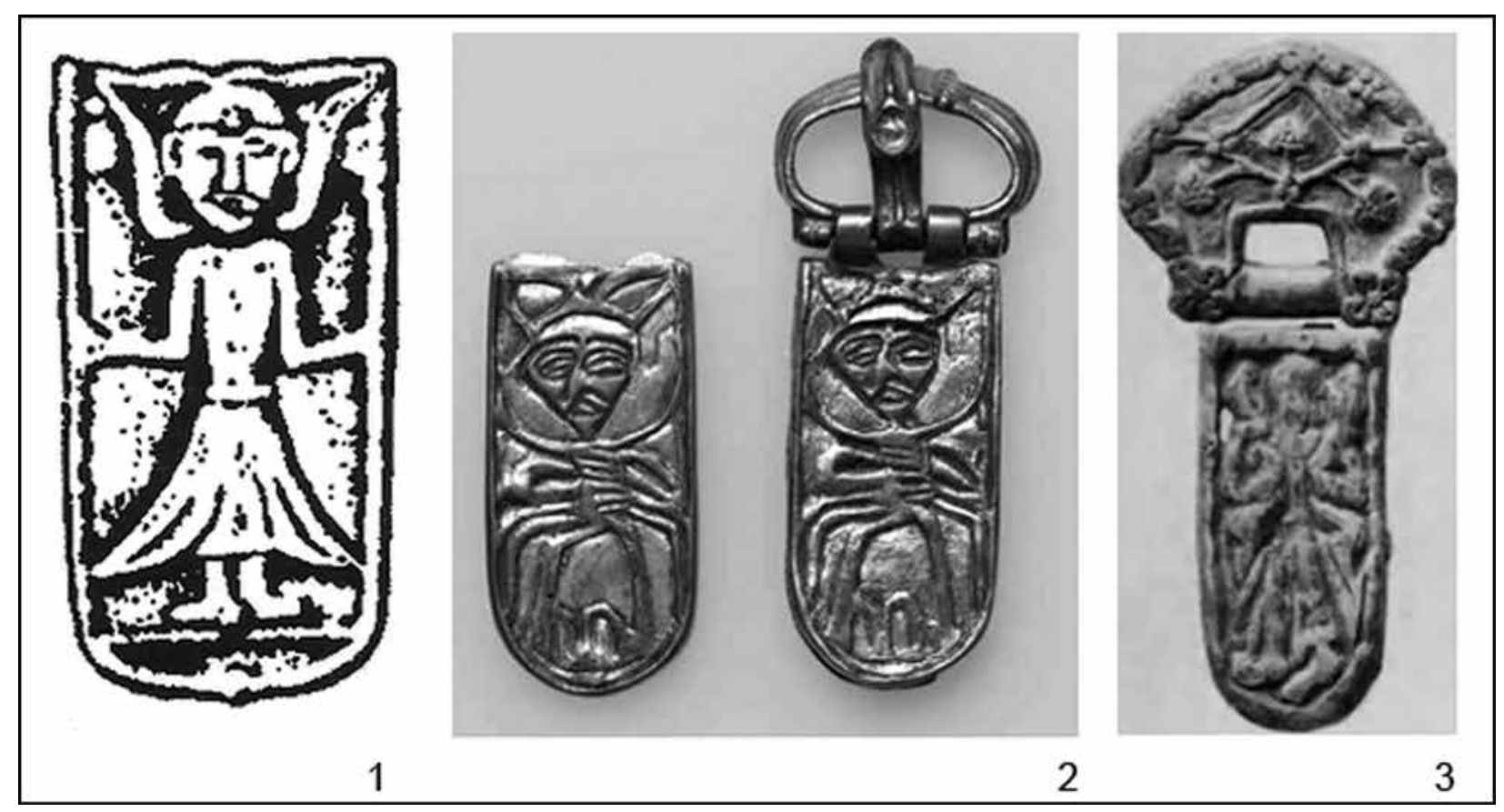

2. kép. Több karú emberalak vereteken. 1: Isimbaj (MAZsitov 1981, 90. puc. 47/1.); 2: Redikor (AHMEDOv-ToRGOJEv 2016, 363.); 3: Novonyikolajevka (HANENKO-HANENKO 1902, t. XIX/679.)

Fig. 2. Human figure with many arms on the belt mounts. 1: Ishimbay (MAZHITOV 1981, 90. fig. 47/1.); 2: Redikor (AHMEDOVTORGOEV 2016, 363.); 3: Novonikolaevka (KHANENKO-KHANENKO 1902, fig. XIX/679.)

46 Миколаївка, Ukrajna.

47 HANENKO 1902, 23., 42., t. XIX/679.
48 Mazsitov 1981, 90.

49 OAK 1909-1910, 228., 230., AHMEdov-Torgojev 2016, 363. 
körül valamiféle fejviseletet, szalagot, esetleg szárnyat akart ábrázolni az ötvös. Az isimbaji szijvégen mintha a fejtetőből indulnának ki kétfelé szalagok. A redikori övvereteken igen sok végtagot ábrázolt a múvész. Ezek értelmezése nehézségekbe ütközik. Az alak dereka körül mintha ugyanolyan fátylak vagy szárnyak látszanának, mint amilyenek a Szubotciban ábrázolt emberalakok körül vannak, de az is lehetséges, hogy azok nem fátylak, hanem az ábrázolt személy behajlított és maga előtt összekulcsolt karjai. A veretek közepén mintha az emberalak ujjai látszanának. A "fátylak”, avagy a behajlított karok fölött másik két kart ábrázolt a múvész fölfelé emelt kartartással. Az övvereteken ábrázolt istenségnek lefelé is két pár karja látható (2. kép 2).

\section{Az övveretek értelmezésének lehetséges keretei}

A pendzsikenti ásatásokon elókerült egy négykarú istennő ábrázolása is. Az istennő fantasztikus állaton ül, fejdíszéhez szalagok kapcsolódnak. ${ }^{50}$ Kelet-Turkesztán buddhista múvészetében is megtalálható a négykarú istenség motívuma. Ez a motívum Indiáig vezethetó vissza. KözépÁzsiában és Kelet-Turkesztánban szogd közvetítéssel terjedt el. ${ }^{51}$ Ugyanakkor a szogd népesség fentebb vázolt szinkretizmusa miatt nehéz meghatározni egy adott múvészeti alkotás jelképrendszerét. A négykarú istenség nemcsak Siva, hanem Anahita is lehet. ${ }^{52}$ Lótuszülésben ábrázolt négykarú istennő látható egy ismeretlen lelőhelyư ezüstcsészén is. Kezében a hold és a nap szimbólumait tartja. ${ }^{53}$ A csésze a NyizsnyijNovgorod-i vásáron bukkant föl. ${ }^{54}$ A 19 . században a Nyizsnyij-Novgorod-i vásár Oroszország legjelentősebb kereskedelmi eseménye volt, vonzáskörébe tartozott az egész Volga-Káma-vidék. Valószínúleg ez az edény is a Káma mellól származik, a „permi ezüstök” körébe sorolható.

A buddhista ikonográfiából ismert négy- vagy többkarú férfiak ábrázolása is. A buddhizmusban különös tisztelet övezi a bódhiszattvákat. Ők olyan emberek, akik már megvilágosodtak, de még nem érték el a nirvánaállapotot. A többi emberért világosodtak meg, és a Tusita-mennyországban arra várnak, hogy mindenki megvilágosodjon. Ilyen bódhiszattva volt Avalókitésvara

50 Ilyen szalagok a Szubotciban talált övveretek emberábrázolásain is vannak.

51 BELENYICKIJ-MARSAK 1976, 77-80.

52 GYJAKONOVA-SZMIRNOVA 1967.

53 BELENYICKIJ-MARSAK 1976, 77; SZMIRnOv 1909, 43. tétel, XVIIIXIX. $t$.

54 SzMIRNOv 1909, XVIII. t.: „a Nyizsnyij-Novgorod-i vásárból, 1875 előtt". is. Ő az Úr, aki lenéz az emberekre, együtt érez és szeret velük. Sok neve van (a tibeti buddhizmusban pl. Csenrézi/Csenrezig ${ }^{55}$ ), sokféleképpen ábrázolják, olykor rengeteg karral is. Az om mani padme hum mantrát a négykarú Csenrézinek kell mondani. E többkarú istenség az égből követte figyelemmel a földi történéseket, óvta az embereket. Ebben a funkciójában azonosítható volt Tengrivel, a türk hitvilág legfőbb istenségével. A szogd kereskedő elit jelenlétének és misszionáriusi tevékenységének ismeretében jó alapunk van feltételezni, hogy az isimbaji és redikori övvereteken egy olyan istenséget ábrázoltak, aki Avalokitésvara/Csenrézi attribútumaival rendelkezik, és személyét valószínúleg azonosították Tengrivel is.

\section{A szubotci 2. sír övének további veretei}

\section{Hatszögletü veretek}

A hatszögletú vereteken jobbra forduló emberalak látható. Mindkét lábát behajlítja. A múvész láthatóan nem statikus állapotban, hanem mozgás (esetleg lebegés?) közben ábrázolta. ${ }^{56} \mathrm{Ez}$ a mozdulat a felugró és éppen levegőben lévő táncos mozdulatára emlékeztet. Karjait behajlítva maga előtt tartja, kezét összezárja. Az emberalak homlokán pánt fogja össze a haját. Feje két oldalán ugyanolyan fátyolszerú tárgy látható, mint a csattest ülő alakjánál. Nyakába sálszerú textília van kötve, amely két oldalra eláll, ugyanúgy, mint a fejénél ábrázolt „fátyol”. A dereka két oldalán további fátyol, vagy szárnyszerú képződmény látható. A leleteket publikáló Bokij és Pletnyova szerint ezt a tárgyat az emberalak a kezében tartja. A táncoló alak bőszárú nadrágját öv fogja össze (3. kép 1).

\section{Függesztőkarikás, ovális alakú veretek}

A függesztókarikás, ovális alakú vereteken térdüket szétvető, lábfejüket összezáró emberek láthatók. A múvész feltehetőleg itt is egy táncmozdulatot kívánt ábrázolni, miként a hatszögletú vereteken. ${ }^{57}$ Ezeken az övvereteken a hatszögletú vereteken ábrázoltakhoz hasonló viseleti tárgyakat és kéztartást ábrázolt a múvész: a fej két oldalából kiinduló fátyolszerú tárgy figyelhető meg,

55 A szogd kereskedelmi-kulturális kapcsolatok Tibetig is elértek. Lásd BÁliNT 2004, 29.

56 Bokij és Pletnyova leírása szerint az ábrázolt alak a bal térdén áll: BOKIJ-PleTNYOVA 1989, 90.

57 Bokij és Pletnyova szerint „az emberi alak ülve van ábrázolva": BOKIJ-PLETNYOVA 1989, 91. E meghatározással ugyanúgy nem értek egyet, mint azzal, hogy a hatszögletú vereten látható alak a bal térdén áll. 
a hajat (és a fátylat?) pánt fogja össze, a karok behajlítva, a kezek ökölbe szorítva, a derék vonalában két oldalon szárnyszerú jelenséget látunk. A jobb minőségú függesztőkarikás vereteken ki- vehető, hogy az ökölbe szorított kezek lótuszt tartanak. Ennek alapján feltételezhetjük, hogy a hatszögletú veretek emberalakjai ökölbe szorított kezükben szintén lótuszvirágot vagy lótuszbim-

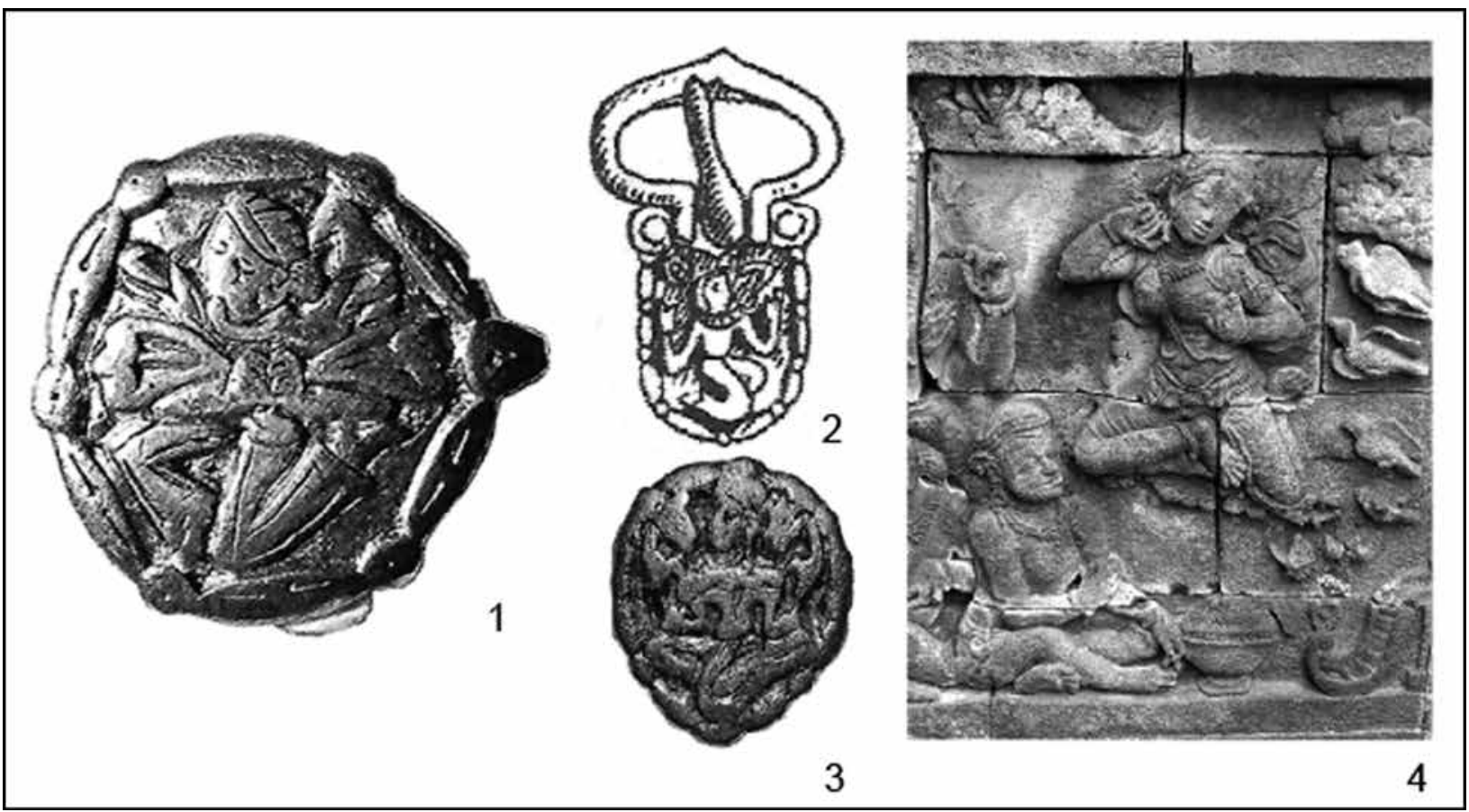

3. kép. Táncoló alakok. 1: Szubotci (Komar 2018, 327. 12. kép/2.); 2: Bolsije Tyigani (HaLIKOvA-HaLIKOv 2018, 124. - XVI/26.); 3: Katyerinovka (Komar 2018, 329. 14. kép/8.); 4: Borobudur, Indonézia (https://commons.wikimedia.org/wiki/File:Apsara_ Borobudur.jpg; letöltve: 2019. 04. 08.)

Fig. 3. Dancing figures. 1. Subotsi (KOMAR 2018, 327. fig. 12/2.); 2: Bolshije Tigani (KhAliKOva-KhaliKOv 2018, 124. fig. XVI/26.); 3: Katerinovka (Komar 2018, 329. fig. 14/8.); 4: Borobudur, Indonesia (https://commons.wikimedia.org/wiki/ File:Apsara_Borobudur.jpg; retrieved: 2019. 04. 08.)

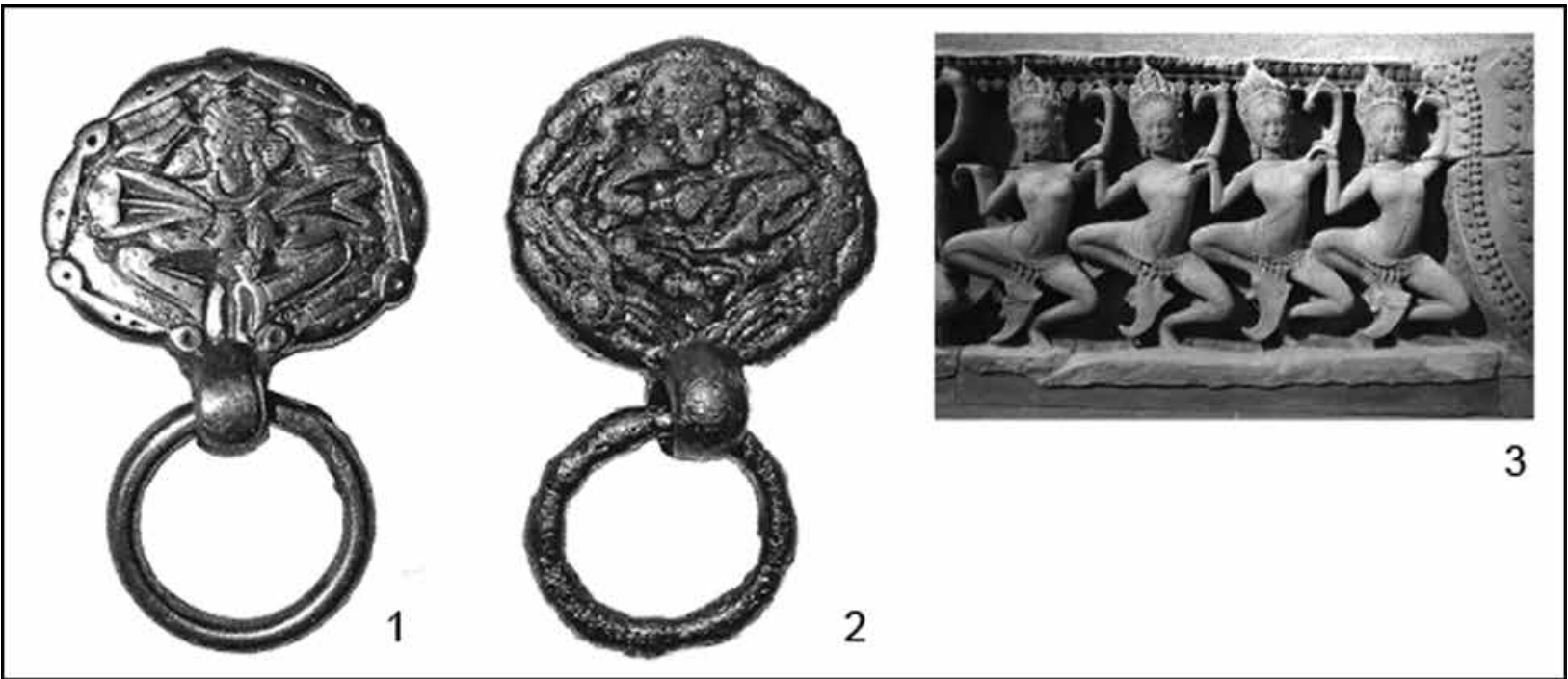

4. kép. Táncoló alakok. 1: Szubotci (Komar 2018, 327. 12. kép/5.); 2: Katyerinovka (Komar 2018, 329. 14. kép/7.); 3: Angkor, Kambodzsa (Musée Guimet, Paris: https://commons.wikimedia.org/wiki/File:Fronton_Guimet_240907_3.jpg; letöltve: 2019. 04. 08.)

Fig. 4. Dancing figures. 1: Subotsi (Komar 2018, 327. fig. 12/5.); 2: Katerinovka (KoMAR 2018, 329. fig. 14/7.); 3: Angkor, Cambodia (Musée Guimet, Paris: https://commons.wikimedia.org/wiki/File:Fronton_Guimet_240907_3.jpg; retrieved: 08. 04. 2019) 


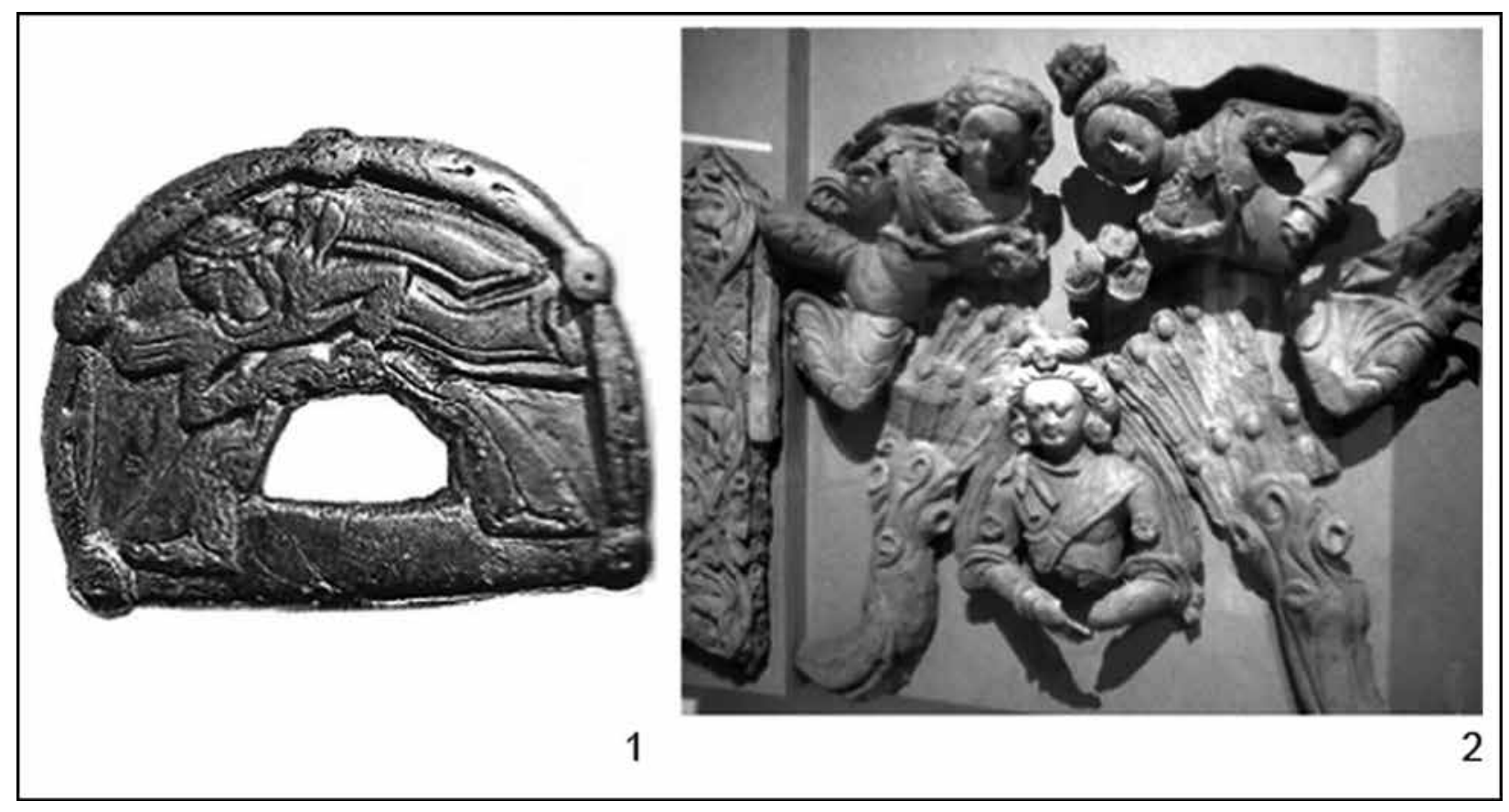

5. kép. Táncoló alakok. 1: Szubotci (Komar 2018, 327. 12. kép/6.); 2: Kelet-Turkesztán (Musée Guimet, Paris: https:// commons.wikimedia.org/wiki/File:SerindianGroup.jpg; letöltve: 2019. 04. 08.)

Fig. 5. Dancing figures. 1: Subotsi (Komar 2018, 327. fig. 12/6.);2: East Turkestan (Musée Guimet, Paris: https://commons. wikimedia.org/wiki/File:SerindianGroup.jpg; retrieved: 2019. 04. 08.)

bót tartanak. ${ }^{58}$ A függesztókarikás vereteken az emberalakok nyakán egyértelmúen nyakpánt látható, míg a hatszögletú veretek esetében inkább arra gondolhatunk, hogy a nyakban megkötött sál látható, melynek végei kétfelé elállnak (4. kép 1).

\section{Áttört függesztônyílásos félkorong alakú veretek}

Az áttört függesztőnyílásos félkorong alakú vereteken a függesztőnyílás fölött látható emberi alak fekve lebegő helyzetben van. Ugyanazon ruházati elemekkel, illetve attribútumokkal ábrázolta őket a múvész, mint a korábban leírt övveretek alakjait. Erról az emberalakról azonban egyértelmúen megállapítható, hogy valamiféle fátylat tart a kezében (5. kép 1).

\section{Az övveretek párhuzamai}

A fentebb leírtakhoz hasonló övveretek ismertek Katyerinovkából, a Szubotci-csoport másik lelőhelyéról is (3. kép 3, 4. kép 2). ${ }^{59} \mathrm{~A}$ Szubotciban talált hatszög alakú veretekhez hasonló formájú, de lekerekített élú vereteken, a függesztókarikás, illetve az áttört függesztőfüles veretek rendkívül

\footnotetext{
58 Lótuszbimbók láthatók a korobcsinói csésze nyakán is (PRIHODNÛK-ČURILOVA 2002).

59 Komar 2011, puc. 8; 2018, 329, 14/5-7. kép.
}

kopottak. A kopás ellenére felismerhető, hogy ezeken a vereteken ugyanolyan mozdulatokkal ábrázolt emberi alakok láthatók, mint a Szubotciból ismert vereteken. A hatszögletú vereteken látható táncoló alak Bolsije Tyigani ${ }^{60}$ temetójének 19. sírjából egy övcsatról ismert (3. kép 2). ${ }^{61}$

\section{Az övveretek táncoló-lebegő alakjai - buddhista ikonográfiai kapcsolatok}

A szubotci második sír további övveretein látható emberalakok elemzésében is a jellemző motívumok segítenek. E motívumok a különleges mozdulatok, a fejdíszek és a fátylak vagy szárnyak. A hatszögletú, a függesztőkarikás és az áttört függesztónyílásos vereteken látható alakokat Bokij és Pletnyova férfiaknak látta, ${ }^{62}$ Komar viszont táncosnak, illetve szárnyas angyalnak nevezte óket, de nemüket nem határozta meg. ${ }^{63}$

Amennyiben a motívumok keresését más múvészeti ágakra (szobrászat, festészet) is kiterjesztjük, akkor megállapíthatjuk, hogy a szubotci ve-

\footnotetext{
60 Halikova 1976; Halikova-Halikov 1981, 2018.

61 HaliKova-Halikov 1981; Halikova-HaliKov 2018, XVI. t./26; KOMAR 2018, 341, 26/7. kép.

62 BoKIJ-PletnYova 1989, 91. „Szemmel láthatólag, jóllehet nincs se szakálluk, se bajuszuk, mind a tizenhét leírt vereten férfiakat ábrázoltak."

63 KOMAR 2016, 550-553., 2018, 119.
} 
reteken táncoló angyallányokat ábrázoltak. Az ötvösmúvészek olyan pózokban ábrázolták őket, amelyek jól ismertek a buddhista ikonográfiában. A táncoló angyalok a buddhista ábrázolásokon látható apszarákra, az égben lakó tündérlányokra, a felhők és az eső szellemeire hasonlítanak. Az apszarák ábrázolásában a szubotci és katyerinovkai veretekról ismert mindkét lábtartás előfordul. A hatszögletú vereteken jobbra forduló emberalak mindkét behajlított lábát egy irányba tartja. Ugyanez a lábtartás ismerhetó fel egy borobuduri (Indonézia) dombormúvön (3. kép 4). Az ovális alakú függesztőkarikás vereteken térdeiket szétvető, lábfejeiket összezáró emberalakokkal azonos lábtartású táncosnők egy Angkorból (Kambodzsa) származó dombormúvön láthatók (4. kép 3).

$\mathrm{Az}$ áttört függesztőnyílásos félkorong alakú vereteken a függesztőnyílás fölött látható emberi alak fekve lebegó helyzetben van. Ehhez párhuzamként a kelet-turkesztáni múvészet köréból ismert dombormú kínálkozik (5. kép 2). Általában az ilyen fekvő helyzetben lebegő angyalokat egy buddha vagy bódhiszattva két oldalán ábrázolják. A párhuzamként kínálkozó dombormúvön az angyalok lábtartása a hatszögletú vereteken látható táncosnő (3. kép 1) lábtartásához hasonló.

\section{A Szubotci-horizont, a Dél-Urál és a Káma-vidék kulturális kapcsolatai az övveretek emberábrázolásainak tükrében}

A Szubotci-típusú leletek sok szállal kötődnek a karajakupovói-kusnarenkovói kultúrához, és azon belül különösen a Bolsije Tyiganiban feltárt temető leleteihez. Erre már a szubotci lelőhely publikálói is utaltak, ${ }^{64}$ és a Szubotci-kör leleteit tárgyaló publikációk azóta is említik és elemzik ezt a kapcsolatot. ${ }^{65}$ Egyre bizonyosabb az a feltételezés, hogy a Szubotci típusú leleteket ránk hagyományozó népesség korábbana karajakupovóikusnarenkovói kultúra területén élt. Az utóbbi években az is egyre nyilvánvalóbbá válik, hogy a Szubotci-horizont és a Kárpát-medencei honfoglaló leletanyagot erôs szálak fúzik a Felső-Kámavidéki lomovatovói leletekhez is. Erről legutóbb Andrej Belavin tartott előadást a IV. Magyar Régészeti Szimpóziumon. ${ }^{66}$ Feltételezhető a szel-

64 BOKIJ-PLETNYOVA 1989.

65 KOMAR 2011; 2018; TÜRK 2011.

66 BELAVIN-KrILASZOVA-DANYICs 2018. A szerzők szerint a 10-11. században magyar maradványnépesség élt a Felső-Káma vidékén. Erről vita folyik a finnugor régészet oroszországi kutatói között (lásd R. D. Golgyina előadását a II. Magyar Szimpóziumon - GolgYiNA 2013, kutatástörténettel). Ehhez kapcsolódik, hogy nyelvészeti adatok alapján is fölmerült a lemi kapcsolat is a Szubotci-horizont és a különböző dél-uráli-Káma-vidéki kultúrák között. ${ }^{67}$

\section{Történeti háttér - a Volgai Bulgár Kánság mint kereskedelmi áruk és kultúrák közvetítője}

A Dél-Urál vidékén a 8-9. század fordulójától a Volgai Bulgár Kánság fogadta és továbbította a különböző irányokból - így a Felső-Káma mellékéről is - a területére érkezó árukat. A szogd kereskedők jelenlétével ezen a területen is számolhatunk. Az erdőövezeti finnugor népektől érkező prémek ellenértékeként az úgynevezett „,keleti ezüstökkel" - a szaszanida-szogd fémmúvesség körébe tartozó korsókkal, tálakkal, csészékkel fizettek. Ezeket fóleg a volgai bulgárok továbbították az Urál hegység mindkét oldalára: a FelsőKáma vidékére és Nyugat-Szibériába is, de a muszlim geográfiai irodalom alapján feltételezhető, hogy a délről érkező kereskedők maguk is eljutottak finnugor területekre: Arúba, Viszúba és a "sötétség országába" ${ }^{6} 8$

A Felső-Káma vidékének a távolsági kereskedelemben való részvétele miatt jogosan gondolhatunk arra, hogy a szogd kereskedők erre a területre is eljutottak. Figyelemre méltó, hogy a Kárpát-medencei honfoglaló magyarság tárgyi kultúrájával szoros kapcsolatot mutató Szubotcikört, a karajakupovói-kusnarenkovói kultúrát és a felső-kámai lomovatovói kultúrát egyaránt megérintették a buddhista-manicheista tanok. A Felső-Káma-vidék már az erdőövezetbe tartozik. A déli eredetú kulturális hatások a kereskedelmi kapcsolatok révén a sztyepptől északra élő népekhez is eljutottak. E témakörben is idézhető tanulmány. ${ }^{69}$ A Felső-Káma vidékének kapcsolatai a sztyeppi kultúrkörrel a régészeti leletekból világosan igazolhatók.

A volgai bulgár állam kereskedelmi szférájába tartozott az ujelgi temetőt ránk hagyó népesség is. E kulturálisan és feltehetőleg etnikailag igen kevert csoport temetójének magyar jellegú leletei között található két övveret, amelyen egy lótusz-

másodlagos magyar-permi finnugor (udmurt, komi) érintkezés lehetősége. A hazai finnugrisztikában erről bizonyító és cáfoló tanulmányok is születtek (RÉDEI 1964, kutatástörténettel). Rédei Károly cáfolta, hogy történt volna ilyen nyelvi érintkezés, azonban a tárgyalt nyelvi jelenségek, valamint a permi finnugor-bolgár-török nyelvi kapcsolatok (lásd RÉDEIRóNA-TAs 1972, 1975, 1980) egy magyar-permi finnugor-volgai bolgár nyelvi háló létezésére engednek következtetni.

67 Lásd a szubotci hatszögletú vereteken lévő táncoló alak párhuzamát Bolsije Tyigani temetőjéból (61. jegyzet).

68 KLIMA 2016, 182-208.

$69 \mathrm{Az}$ udmurt mitológia védikus gyökereiról lásd IvANOVAKULIKOV 1995. 
ülésben ülő emberalak mindkét kezében felemelve tart valamit. ${ }^{70} \mathrm{Ez}$ a motívum a már említett ismeretlen lelőhelyú, a Nyizsnyij-Novgorod-i vásáron felbukkant csésze nőalakját idézi, aki két kezében a hold és a nap szimbólumait tartja.

\section{Összefoglalás}

A Kárpát-medencébe betelepült magyarságnak fennmaradtak a közép-ázsiai és volgai bulgár kapcsolatai. Anonymus szerint Taksony fejedelemsége alatt „Bulárföldről nagyon sok izmaelitával jöttek némely fölötte nemes urak: Billa meg Baks. [...] Ugyanebben az időben, ugyanarról a tájékról jött egy Hetény nevú igen nemes vitéz" ${ }^{71}$ A kapcsolat az államalapítás és a kereszténység felvétele után is tovább élt: az Árpádházi királyok uralkodása idején a kálizoknak ${ }^{72}$ nevezett, feltehetóleg túlnyomórészt szogd származású közép-ázsiai kereskedelmi-pénzügyi elit részt vett a magyar állam gazdasági életében, sőt gazdaságának irányításában is, de ők már muszlim vallásúak voltak. ${ }^{73}$ Közép-Ázsiában az arab hódítás után a helyi népesség fokozatosan áttért a muszlim hitre. Ez a folyamat a 9-10. század fordulóján zárulhatott le. ${ }^{74}$

A magyarság elődeinek vallási elképzeléseiben egymás mellett élhettek a saját és idegen eredetû́ hiedelmek. Feltételezhető, hogy az állatábrázolások és a növényi ornamentika egyes elemei is a mitológia körébe tartozó történetekre utaltak.
A motívumok értékelése során azonban indokolt az óvatosság: egyes népek körében jól dokumentálható az idegen eredetú tárgyak kultikus tisztelete, és az idegen eredetú motívumok beépítése saját hitvilágukba. Obi-ugor néprajzi expedíció gyújtéséból került múzeumba egy 5 . századi szaszanida tál (2001-ben!), szintén néprajzi gyújtésből ismertek 7-9. századi kisplasztikák és újkori, lovakat ábrázoló gyerekjátékok, melyek az obi-ugoroknál kultikus tiszteletben részesültek, szertartások kellékei voltak. ${ }^{75} \mathrm{E}$ példák arra figyelmeztetnek, hogy a buddhista/manicheista motívumok jelenléte a korai magyarság körében nem feltétlenül jelenti ezen vallások alapjainak ismeretét. Egy motívum terjedhet divatjelenségként is. Ugyanakkor feltételezhetjük - még ha bizonyítani nem is tudjuk -, hogy a motívumot megörökítő múvész és a motívummal díszített tárgy megrendelője közül legalább az egyikük tisztában volt a motívum jelentésével.

A manicheizmus forrásait közlő kötetben Simon Róbert azt írta, hogy sajnos egyelöre nem született tudományos monográfia a selyemút és a szogd kereskedők szerepéról a manicheizmus terjesztésében, valamint a manicheizmus és a buddhizmus együttéléséről. Feldolgozásra vár a szogdok történeti, gazdasági és vallási szerepe is a kereskedelmi vonzáskörükbe vont népeknél. ${ }^{76}$ Véleményem szerint e munkák megírása során az itt bemutatott kisebb régészeti leleteket is figyelembe kell venni.

\section{IRODALOM}

AHMEDOV, IlJA RAFAELJEVICS-TORGOJEV, AsZAN IsZAKBEKOVICS

2016 (Ахмедов, И. Р.-Торгоев, А. И. ред.) Путешествие Ибн Фадлана: Волжский путь от Багдада до Булгара. Каталог выставки. Москва, Издательский дом Марджани - Ibn Fadlan's Journey: Volga Route from Baghdad to Bulghar. Exhibition Catalogue. Moscow

AKSZJONOV, VIKTOR SZTYEPANOVICS

2001 (Аксенов, В. С.) Редкий тип бляшек-амулетов из Верхнесалтовского катакомбного могильника. In: Культуры Евразийских степей второй половины I тысячелетия н. э. (из истории костюма). Материалы III Международной археологической конференции, т. 2. Самара, 132-140.

ANONYMUS

1977 Gesta Hungarorum. Ford. és jegyz. Pais Dezső, bev., jegyz. és térkép Györffy György. Budapest BÁLINT CSANÁD

1970 A ló a pogány magyar hitvilágban. Móra Ferenc Múzeum Évkönyve 1970/1. (Szeged) 31-43.

70 A két övveret Szergej Botalov több publikációjából ismert, legutóbb: BOTALOV 2018, 21.

71 ANONYMUS 1977, 132.

72 A magyar nyelv káliz szava Horezm nevéből származik (HARMATTA 1994).

73 E témakörról lásd ZiMONYI 2009, 22.

74 Ibn Fadlán 921-922-ben keletkezett úti jelentéséből látható, hogy az iszlám akkor már a volgai bulgárok körében is teret hódított (SIMON 2007).

75 Erről ismeretterjesztő formában írtam, de a szakirodalom felsorolásával: KLIMA 2012.

76 SIMON 2011, 411/192. jegyzet, 420/231. jegyzet. 
1971 A kutya a X-XII. századi magyar hitvilágban. Móra Ferenc Múzeum Évkönyve 1971/1. (Szeged) 295-315.

2004 A nagyszentmiklósi kincs. Régészeti tanulmányok. Budapest.

Belavin, Andrej Mihajlovics-Krilaszova, Natalja Boriszovna-Danyics, Andrej Vasziljevics

2018 (Белавин, А. М.-Крыласова, Н. Б.-Данич, А. В.) Венгерские (мадьярские) черты погребального обряда средневековых могильников Предуралья. In: Ситдиков, А. Г. (гл. ред.): Материалы IV Международного Мадьярского симпозиума. Казань-Болгар, 15-19 окттября 2018 г. Археология Евразийских Степей № 6 2018. Казань, 8-12.

BELENYICKIJ, ALEKSZANDR MARKOVICS-MARSAK, BORISZ ILJICS

1976 (Беленицкий, А. М.-Маршак, Б. И.) Черты мировоззрения согдийцев VII-VIII вв. в искусстве Пенджикента. In: История и культура народов Средней Азии (древность и средние века). Москва, 75-89., 179-186. (ill.)

BERJOZKIN, JURIJ JEVGENYJEVICS

2007 (Березкин, Ю. Е.) Мифы заселяют Америку: Ареальное распределение фольклорных мотивов и ранние миграции в Новый Свет. Москва.

Bokij, NinYel Mihajlivna-Pletnyova, SZVETlana AleKsZANDrovna

1988 (Бокий, Н. М.-Плетнева, С. А.) Захоронение семьи воина-кочевника Х в. в бассейне Ингула. Советская Археология (Москва) 2, 99-115.

1989 Nomád harcos család 10. századi sírjai az Ingul folyó völgyében. Archaeologiai Értesítő (Budapest) 116, 86-98.

BOLLÓK ÁDÁM

2015 Ornamentika a 10. századi Kárpát-medencében. Formatörténeti tanulmányok a magyar honfoglalás kori díszítőmúvészethez. Budapest.

Botalov, Szergej GenNagyjeVics

2018 (Боталов, С. Г.) Урало-Алтайское единство в материалах погребального комплекса Уелги. In: Ситдиков, А. Г. (гл. ред.): Материалы IV Международного Мадьярского симпозиума. Казань-Болгар, 15-19 октября 2018 г. Археология Евразийских Степей № 6 2018. Казань, 13-34.

COMPARETTI, MATtEO

2011 The Painted Vase of Merv in the Context of Central Asian Pre-Islamic Funerary Tradition. The Silk Road, 9., 26-41.

DEMÉNY ISTVÁN PÁL

2002 Táltosok, kerekek, lángok. Csíkszereda.

ELVERSKOG, JOHAN

2010 Buddhism and Islam on the Silk Road. Philadelphia.

FANCSALSZKY GÁBOR

2007 Állat- és emberábrázolások a késő avar kori öntött bronz övvereteken. Budapest.

FODOR ISTVÁN

1999 A sas szerepe a honfoglaló magyarság hitvilágában. In: Kisné Cseh Julianna (szerk.): Magyarok térben és időben. Tata, 141-161.

FOLTZ, RICHARD C.

1999 Religions on the Silk Road. Overland Trade and Cultural Exchange from Antiquity to the Fifteenth Century. New York, St. Martin's Griffin; 2nd edition: Religions of the Silk Road: Premodern Patterns of Globalization. New York.

Golgyina, Rimma DMitrijeVNA

2013 (Голдина, Р. Д.) Некоторые замечания относительно формирования теории угорского присутствия в предуралье в эпоху средневековья. In: (Отв. ред. С. Г. Боталов, Н. О, Иванова) II-й Международный Мадьярский симпозиум. 13-17 августа 2013 г. Челябинск, 89-110.

GuLÁCSI, ZsuZsANNA

2009 A Manichaean Portrait of the Buddha Jesus: Identifying a Twelfth-Thirteenth-century Chinese Painting from the Collection of Seiun-ji Zen Temple. Artibus Asiae 69/1, 91-145.

2015 „Images of Jesus in Manichaean Art.” In: Richter, S. (ed.): In Mani In Dublin: Selected Papers from the 7th International Congress of Manichaean Studies, September 8-14, 2009, Dublin, Ireland. Nag Hammadi and Manichaean Studies. Leiden, 185-195.

GyjaKonOva, Natalja VasziljeVna-Szmirnova, Olga IVAnOvna

1967 (Дьяконова Н. В.-Смирнова О. И.) К вопросу о культе Наны (Анахиты) в Согде. Советская Археология (Москва) 1, 74-83.

Halikova, Jelena AleKSZANDrovna

1976 Ősmagyar temető a Káma mentén. Magna Hungaria kérdéséhez. Archaeológiai Értesítő (Budapest) 103, 53-78.

Halikova, Jelena Alekszandrovna-Halikov, Alfred Haszanovics

1981 Altungarn an der Kama und im Ural. Régészeti Füzetek Ser. II/15. Budapest.

2018 (Халикова, Е. А.-Халиков, А. Х.) Ранние венгры на Каме и Урале (Больше-Тиганский могильник). Археология Евразийских степей, приложение к журналу, Выпуск 25. Казань 
HANENKO, BOGDAN IVANOVICS-HANENKO, VARVARA NYIKOLAJEVNA

1902 (Ханенко Б.-Ханенко, В.) Древности Приднепровья. Вып. V. Киев

HARMATTA JÁNOS

1994 Kálizok. In: Korai Magyar Történeti Lexikon (9-14. század). Főszerk. Kristó Gyula. Budapest, 314.

HopPÁL MiHÁly

2014 A magyar ősvalláskutatás (új) útjai. In: Magyar őstörténet. Tudomány és hagyományőrzés. MTA BTK MÖT Kiadványok I. Budapest, 231-238.

IVANOVA, MARgarita GrigorJeVna-KuliKov, KuZMa IVANOVICS

1995 (Иванова М. Г.-Куликов К. И.) Тайны умолкнувших символов. Ведийские корни удмуртской мифологии. In: Памятники Отечества. Полное описание России. Вып. 33. № 1-2, Удмуртия. Москва, 28-34.

KLIMA, LÁSZLÓ

2012 Szakrális Játékok. Istenek és falovacskák. Nyelv és Tudomány, 2012. június 8. - https://www.nyest.hu/ renhirek/istenek-es-falovacskak

2016 Jürkák, tormák, merják. Szemelvények a finnugor nyelvú népek történetének korai forrásaiból. Források és tanulmányok 1. Budapest

2018 Eastern Religious Motifs on the Belt Mounts of Subotsi Group, Kushnarenkovo Culture and Lomovatovo Culture. In: Ситдиков, А. Г. (гл. ред.): Материалы IV Международного Мадьярского симпозиума. КазаньБолгар, 15-19 окттября 2018 г. Археология Евразийских Степей № 6 2018. Казань, 136-149.

KOMAR, OleKSZIJ VIKTOROVICS

2011 (Комар, А. В.) Древние мадьяры Этелькеза: перспективы исследований. In: Мадяри в Середньому Подніпров>ї. Археологія і давня історія України. Вып. 7. Київ, 21-76.

2016 (Комар, Алексей В.) Поясные наборы IX-X вв. с «мифологическими сюжетами». In: Bollók, Á.-Csíky G.Vida T. (eds): Zwischen Byzanz und Byzantinum and the Steppe. Archaeological and Historical Studies in Honour of Csanád Bálint on the Occasion of His 70 th Birthday. Budapest, 545-556.

2018 (Комар, Алексей/Komar, Olekszij) История и археология древних мадьяр в эпоху миграции/A korai magyarság vándorlásának történeti és régészeti emlékei. PPKE BTK Régészeti Tanszékének Kiadványai 11/ MTA BTK MŐT Kiadványok 5/Ómúltunk Tára 14. Budapest.

Korol, GaLina GeORGIJEVNA

2005 (Король, Г. Г.) Антропоморфно-сюжетные изображения на ременных украшениях кочевников Евразии конца I начала II тыс. н.э. In: Тишкин, А. А. (ред.): Снаряжение кочевников Евразии. Барнаул, 157-162.

KÓSA GÁBOR

2008 "A létezók átváltozása” A pillangó motívuma a Zhuangziben. Vallástudományi Szemle (Budapest) 4:1, 93-108.

LANGÓ PÉTER

2007 Amit elrejt a föld... A 10. századi magyarság anyagi kultúrájának régészeti kutatása a Kárpátmedencében. Budapest.

LITVINSKY, BORIS A.

1968 Outline history of Buddhism in Central Asia. Moscow.

LŐRINCZ LÁSZLÓ

1975 Mongol mitológia. Kőrösi Csoma Kiskönyvtár 14. Budapest.

LUKONYIN, VLAGYIMIR GRIGORJEVICS

1967 (Луконин, В. Г.) Кушано-сасанидские монеты. Эпиграфика Востока, вып. XVIII. Москва, 16-33.

MAENCHEN-HelFen, OTto

1951 Manicheans in Sibiria. in: W. J. Fischel, W. J. (ed.): Semitic and Oriental Studies. Presented to W. Popper on the Occasion of his Seventy-Fifth Birthday Oct 29, 1949. (Univ. of California Publ. In Semitic Philology 11). Berkeley-Los Angeles, 311-326.

MAROSI ERNŐ

1996 A honfoglalás a múvészetben. Magyar Tudomány (Budapest) 103, 1026-1034.

MaZSITOV, NYIJAZ AbDULHAKOVICS

1981 (Мажитов, Н. А.) Курганы Южного Урала VIII-XII вв. Москва.

MESTERHÁZY KÁROLY

1994 Többgyökerú ősi vallásunk emlékei. In: Kovács L. (szerk.): Honfoglalás és régészet. Budapest, 195-205.

NAPOLSKIKH, VLADIMIR V.

1989 The Diving-Bird Myth in Northern-Eurasia. In: Hoppál, M.-Pentikäinen, J. (eds): Uralic Mythology and Folklore. Ethnologica uralica 1. Budapest-Helsinki.

OAK

1909-1910 Отчет Императорской Археологической Комиссии за 1909 и 910 годы (1913). Санктпетербург.

PARRY, KEN

2005 The Iconography of the Christian Tombstones from Quanzhou. In: Lieu, S.-I. Gardner, I.-Parry, K. (eds): From Palmyra to Zayton: Epigraphy and Iconography. Silk Road Studies X. Turnhout, 229-246.

Petruhin, Vlagyimir Jakovlevics

2014 (Петрухин, В. Я.) Русь в IX-X веках. От призвания варягов до выбора веры. 2-е издание. Москва. 
PriHODNÛK, Oleg M-ČURILOVA, LARISA M.

2002 The Korobčino find (Ukraine) and some problems of the hungarian ethnogenesis. Acta Archaeologica PURI, BAIJ NATH Academiae Scientiarum Hungariae (Budapest) 53, 183-193.

1987 Buddhism in Central Asia. Buddhist Tradition Series, Vol 4, Delhi.

RÉDEI KÁROLY

1964 Vannak-e az előmagyar-permi érintkezésnek nyelvi nyomai? Nyelvtudományi Közlemények (Budapest) $66,253-261$.

RÉDEI KÁROLY-RÓNA-TAS ANDRÁS

1972 A permi nyelvek őspermi kori bolgár-török jövevényszavai. Nyelvtudományi Közlemények (Budapest) 74, 281-298.

1975 A bolgár-török-permi érintkezések néhány kérdése. Nyelvtudományi Közlemények (Budapest) 77, 31-44.

1980 Őspermi és votják jövevényszavak a csuvasban. Nyelvtudományi Közlemények (Budapest) 82, 125-133.

RÓNA-TAS, ANDRÁS

1991 An Introduction to Turkology. Studia Uralo-Altaica 33. Szeged.

SIMON RÓBERT

2007 (ford., szerk. és utószó) Ibn Fadlán: Beszámoló a volgai bolgárok földjén tett utazásról. Fontes Orientales-Keleti Források. Budapest.

2011 Simon Róbert - Simonné Pesthy Monika (szerk.): Máni és a fény vallása. A manicheizmus forrásai. Budapest.

SZMIRNOV, JAKOV IVANOVICS

1909 (Смирнов, Я.И.) Восточное серебро. Атлас древней серебряной и золотой посуды восточного происхождения, найденной преимущественно в пределах Российской империи. Санкт-Петербург.

TORGOJEV, ASZAN ISZAKBEKOVICS

2012 (Торгоев, А. И.-Кий, Е. А.-Кольченко, В. А.-Викторова, О. С.-Казимирова, Р. А.-Кулиш, А. В.) Новый буддийский памятник в чуйской долине (Северная Киргизия). Сообщения Государственного Эрмитажа LXX. Санкт-Петербург, 191-200.

TÜRK ATTILA

2011 A magyar őstörténet és a szaltovói régészeti kultúrkör. PhD kézirat, Szeged.

Voigt Vilmos

1974 Hozzászólás Balassa I.: Mivel járulhat hozzá a néprajztudomány a honfoglaló magyarság életmódjának a kutatásához? címú vitacikkéhez. Ethnographia (Budapest) 88, 603-604.

1977 Folklorisztika és őstörténet. In: Bartha A.-Czeglédy K.-Róna-Tas A. (szerk.): Magyar őstörténeti tanulmányok. Budapest, 305-318.

ZARIPOV, NUR TALIPOVICS

1987 (Зарипов, Н. Т.) (гл. ред.) Башкирское народное творчество. т. 1. Эпос. Уфа.

ZIMONYI ISTVÁN

2009 Az iszlám és a középkori Kelet-Európa. In: Térítés - Megtérés. A világvallások terjedése Kelet-Európa népei között. Magyar Őstörténeti Könyvtár 25. Budapest, 11-28. 


\section{EASTERN RELIGIOUS MOTIFS IN ARCHAEOLOGICAL CULTURES CONNECTED TO EARLY HUNGARIANS}

\section{LÁSZLÓ KLIMA}

Depictions of animals or humans are much rarer than ornaments with plant motifs among the archeological finds from the Hungarian conquest. This is the reason why the finds from the cemetery of three graves excavated in Subotsi, Ukraine and published in 1988/1989 attracted attention, as here, all the four types of belt mounts found in Grave 2 depict human figures. This cemetery is regarded as part of the early Hungarian history (its dating is debated, it was probably used in the middle of the $9^{\text {th }}$ century).

The old man depicted on the buckle plate is sitting in lotus position, giving blessings with his right hand. These motifs suggest connections to both Buddhism and Christianity. The old man is holding a stick in his left hand. This might be a T-shaped crosier, although might also allude to the belief system of Turkish and Mongolian peoples. The figure of an old man with a long beard, who walks with a stick and does justice to people often appears in the folkloric texts of these peoples. The figure of the old man depicted on the buckle plate from Subotsi can be recognized on a belt mount from Verkhniy Saltov, Ukraine.

Parallels for the figures with special leg positions on the hexagonal and pendant belt fittings with a ring from Subotsi are known from Buddhist works of art. Apsaras, i.e. the celestial female spirits of clouds and rain were depicted in a similar manner. The figures above the holes of the half-disc formed belt mounts are floating. In Buddhist iconography, figures in this position generally appear around Buddhas and Bodhisattvas. This motif indicates that the depicted figures - i.e. Buddhas, Bodhisattvas and the floating spirits floating around them are all in another world. Dancing/floating female spirits were excavated at the Katerinovka site, which also belongs to the Subotsi Horizon. The leg position appearing on the hexagonal belt mounts - the leg is depicted from the side, legs face the same direction, knees are bent - can also be recognized on a buckle plate from Grave 19 of the cemetery in Bolshie Tigani, Russia.

A four-armed godly figure is known from the Ishimbay, Russia excavation site from the Southern Ural Mountains. Belt mounts from Redikor on the River Upper Kama depict a god with four or six arms. This motif also originates from the Buddhist cultural sphere. With the help of belt mounts from Ishimbay and Redikor, it is recognizable that the heavily worn belt mount from Novonikolaevka, related to the Subotsi Horizon also depicts a multi-armed god. This god with several arms can be identified with Bodhisattva Avalokiteśvara/Chenrezik, who watches events on the Earth from the sky and protects people. Tengri, the Turkic god of the sky has the same function.

Merging Buddhist, Christian and heathen mythological elements was characteristic of Manichaeism. Both Buddhism and Manichaeism were spread by Sogdian merchants, who traded along the Silk Road and also settled among local people. These merchants started out from the direction of Khwarazm and reached as far as the Volga Bulgarian Khanate. Their teachings spread among the trading partners of Bulgarians as well. This explains why belt mounts depicting human figures with Buddhist/ Manichaeist influence are to be found along the Upper Kama and in the Southern Urals. Early Hungarians learnt about the Buddhist/Manichaeist gods and spirits from the same source.

Having settled in the Carpathian Basin, Hungarians kept contact with Volga Bulgarians (cf. Anonymus) and merchants from Central Asia. Khwarezmian merchants known from sources from the Árpád era were, however, muslims.

A cikk a Creative Commons Attribution 4.0 International License (https://creativecommons.org/licenses/by/4.0) feltételei szerint publikált Open Access közlemény, melynek szellemében a cikk bármilyen médiumban szabadon felhasználható, megosztható és újraközölhető, feltéve, hogy az eredeti szerző és a közlés helye, illetve a CC License linkje és az esetlegesen végrehajtott módosítások feltüntetésre kerülnek. (SID_1) 
